\title{
Partycypacja budżetowa jako element rozwoju społeczeństwa obywatelskiego. Propozycja dla Ukrainy
}

\section{Participatory budgeting as the element of civil society development - formal plan for Ukraine}

\section{Streszczenie:}

Artykuł ten jest propozycją implementacji samorządowych rozwiązań budżetowych mogących wpłynąć na aktywność obywatelską modernizującej się Ukrainy. W tym celu zastosowany zostanie instrument partycypacji społecznej - budżet partycypacyjny, który stał się wiodącym przykładem pobudzania aktywności lokalnych wspólnot niemal na całym świecie. Zostaną tu przedstawione jego dwa modele. Pierwszy pochodzi z Brazylii, a drugi z Polski. Na przykładzie dwóch miast, Porto Alegre oraz Łodzi, zostanie zaprezentowany mechanizm działania obu tych rozwiązań w przestrzeni samorządowej, a w dalszej kolejności będą one poddane weryfikacji pod względem ich funkcjonalność w wymiarze ukraińskim.

Słowa kluczowe: Ukraina, budżet obywatelski, partycypacja społeczna, kapitał społeczny, społeczeństwo obywatelskie, kultura polityczna

\begin{abstract}
:
In my article I suggest two models of social participation which can positively influence on the process of building the civil society in Ukraine, especially in the area of local government. I want to consider two types of the
\end{abstract}


Mateusz Radziszewski - Partycypacja budżetowa...

participatory budgeting, first comes from Porto Alegre in Brazil and the second one from Lodz in Poland. The first model, 27 years old, is the example of representative democracy and is characterized by hierarchical structure. On the other hand, we have different model which is the representative of participatory democracy without any gradation. In this area of research I'm going to choice the best proposition which fit in the process of political transition on Ukraine.

Keywords: Ukraine, participating budget, participation, social capital, civil society, political culture

\section{Wstęp}

Ukraina stoi przed ogromnym wyzwaniem wewnętrznej modernizacji państwa. Rewolucja obalająca rosyjskiego stronnika, prezydenta Wiktora Janukowycza, ujawniła skalę zapaści kraju oraz degeneracji jej struktur administracyjnych. To jednak nie wszystkie zmartwienia Ukraińców. Zajęcie Półwyspu Krymskiego przez Rosję oraz stale przez nią inspirowane walki we wschodnich obwodach $\mathrm{z}$ prorosyjskimi separatystami znacznie obciążają finanse publiczne, prowadząc do zapaści ekonomicznej, m. in. z powodu utraty przez Ukrainę ważnego ośrodka przemysłowego ${ }^{1}$. Innym istotnym aspektem toczących się walk są druzgocące w skutkach problemy społeczne, objawiające się nie tylko sporami między rosyjską mniejszością i Ukraińcami, ale również znaczącym rozwarstwieniem społeczeństwa na zachodnią i wschodnią częścią państwa. W takiej samej sytuacji znajdują się Ukraińcy zamieszkujący Krym, których relacje z kontynentalną częścią kraju są w znacznym stopniu utrudnione. Należy zatem zastanowić się nad możliwościami pomocy Ukrainie nie tylko w wymiarze militarnym i gospodarczym, ale również społecznym.

\footnotetext{
${ }^{1}$ Na terenie obwodów donieckiego i ługańskiego znajduje się okręg przemysłowy o nazwie Donieckie Zagłębie Węglowe.
} 
Przemiany na Ukrainie zmuszają do refleksji nad rozwojem społecznym państwa. Czy wielki wysiłek jaki został poczyniony przez Ukraińców, czyli wyjście ze strefy wpływów rosyjskich oraz dążenie do dynamicznego rozwoju Ukrainy na wzór zachodnich demokracji zostanie zaprzepaszczony? Poszukując odpowiedzi na to pytanie należy odwołać się do podstawowego elementu polityki, który jest domeną społeczeństwa, a mianowicie aktywność obywatelska². Nie ulega wątpliwości, że stanowi ona niezwykle istotny aspekt funkcjonowania demokratycznego państwa. To w dużej mierze od jej skali oraz intensywności zależy, czy obywatele mogą cieszyć się bezpieczeństwem oraz dobrobytem. Naturalnie to nie jedyny czynnik, który wpływa na homeostazę systemu politycznego, jednakże analiza doświadczeń polskich i brazylijskich w sferze budowy społeczeństwa obywatelskiego pokazuje, że jako jeden z niewielu umożliwia wypracowanie wśród przedstawicieli społeczeństwa zdolności zdawania sobie sprawy z rzeczy ważnych dla wspólnoty jako kolektywnego punktu odniesienie wszystkich mieszkańców³.

Aktywność obywatelska nie zawsze przyjmuje postać świadomej „roztropnej troski o dobro wspólne” 4 . Dostrzegalne jest zarysowywanie się dwóch nurtów myślenia o aktywnościach obywatelskich. Pierwszy z nich opiera się na afektywnym stosunku do polityki, który wielokrotnie współgra z głoszenie radykalnych haseł i uczestnictwem w wydarzeniach organizowanych przez stronnictwa polityczne skrajnie prawicowe lub lewicowe. $\mathrm{W}$ tym przypadku mamy do czynienia z postrzeganiem sfery polityki jako walki, a oponenta politycznego, jako wroga ${ }^{5}$. Powodem tego jest silne emocjonalne nacechowania bieżących wydarzeń politycznych, na temat których społeczeństwo

${ }^{2}$ Zob. R. Putnam, Samotna gra w kręgle, upadek i odrodzenie wspólnot lokalnych w Stanach Zjednoczonych, Warszawa 2008, s. 6.

${ }^{3}$ Zob. A. Baur, Szwajcarski fenomen, Warszawa 1993.

4 Parafraza słów Arystotelesa mówiącego o tym, czym powinna być polityka. Zob. Arystoteles, Polityka, Warszawa 2006.

${ }^{5}$ Zob. R. Klamut, Aktywność obywatelska jako rodzaj aktywności społecznej - perspektywa psychologiczna, „Studia Socjologiczne” 2013, nr 1 (208), s. 188. 
Mateusz Radziszewski - Partycypacja budżetowa...

wyrabiając własne zdanie, a priori opowiada się za określoną opcją polityczną, jednocześnie wpisując się w rywalizację zawodowych polityków6.

W drugim przypadku aktywność obywatelska nazywana jest działaniem będącym odwróceniem lub wręcz zaprzeczeniem tzw. „wielkiej polityki”. Obszarem działalności społeczeństwa jest tutaj wspólnota samorządowa, która realizuje własne potrzeby i rozwiązuje bieżące problemy. Wyróżniającą cechą jest tutaj to, że wszyscy obywatele (mieszkańcy), stanowią społeczność poprzez miejsce zamieszkania, a nie ideologię, czy wizję państwa. To miejsce w którym żyją, powstająca między nimi sieć zależności, ich nieustanne wchodzenie w relacje społeczne z innymi ludźmi umożliwia stworzenie wspólnoty wyobrażonej, która może współdziałać dla wspomnianego dobra wspólnego ${ }^{7}$.

Obie wizje aktywności obywatelskiej są doskonale znane i nieustannie omawiane zarówno w dyskursie naukowym jak i publicznym. Zarysowane między nimi wyraźne różnice zmuszają do refleksji nad tym, jak sprawić, aby polityka nie stała się areną walk zwalczających się stronnictw o odmiennych ideologiach, czy mówiąc ogólniej wizjach świata, lecz była płaszczyzną współpracy, determinującą synergię społeczną, przeciwdziałając powielaniu się i umacnianiu antagonizmów między ludźmi. Jednym z rozwiązań dążących w tym kierunku jest wykorzystanie obecnie dostępnych instrumentów angażujących społeczeństwo w sprawy publiczne. Przykładem tego jest budżet partycypacyjny. Instrument pozwalający na zaangażowanie społeczeństwa w polityczny proces decyzyjny na szczeblu samorządowym. Jego powstanie, niemal trzy dekady temu, zapoczątkowało narastanie przeświadczenia wśród dotychczasowych i nowych aktorów na scenie politycznej, że społeczeństwo to nie tylko bezimienne

${ }^{6}$ Zob.: H. A. Giroux, D. Bhattacharya, Anti-politics and the scourge of authoritarianism, „Social Identities” 2016, s. 5; J. Czapiński, T. Panek, Diagnoza Społeczna 2015 Warunki i jakość życia Polaków, Warszawa 2015; http://parlament2015.pkw.gov.pl/ 349_wyniki_sejm (dostęp: 10.08.2016).

${ }^{7}$ R. Putnam, Demokracja $w$ działaniu. Tradycje obywatelskie we współczesnych Włoszech, Warszawa 1993, s. 126. 
zbiorowisko osób, które wyrażają swoją wolę w rozmaity sposób, spośród których najbardziej „cywilizowanym” jest oddanie do urny wyborczej głosu na swojego przedstawiciela w organach władzy. Politycy zrozumieli wreszcie, że obywatele to realni partnerzy, mogący wpływać na otoczenie, będący zdolni do poświęcenia oraz chętni do pracy na rzecz własnej zbiorowości.

Budżet partycypacyjny to instrument umożliwiający na zasadach partnerskich władzom samorządowym oraz mieszkańcom współdecydować o tym, w jaki sposób zostaną rozdysponowane publiczne środki. Mechanizmów funkcjonowania tej zależności jest wiele. W niniejszym artykule zostaną przedstawione dwa. Pierwszym z nich jest klasyczny model budżetu partycypacyjnego, pierwszego powstałego $\mathrm{w}$ Porto Alegre w Brazylii pod koniec lat 80. XX wieku ${ }^{8}$. Jego cechą charakterystyczną, mającą duże znaczenie dla kształtowania się aktywności obywatelskiej jest to, że jest to mechanizm inkluzji politycznej w wymiarze demokracji przedstawicielskiej. Drugi natomiast pochodzi z Polski, gdzie cieszy się on wielką popularnością wśród mieszkańców wielu miast. W tym przypadku budżetem obywatelskim poddanym analizie będzie ten organizowany od $2012 \mathrm{w}$ Łodzi $^{9}$. Cechą charakterystyczną dla niego jest to, że mieszkańcy uczestniczą w podejmowaniu decyzji na zasadach demokracji uczestniczącej, samodzielnie i bezpośrednio wpływając na ostateczne rozwiązania, czyli cel wydatków.

\section{Rozwoju społeczeństwa obywatelskiego - założenia metodologiczne}

Niniejszy artykuł ma charakter deskryptywno-eksplanacyjny i stanowi propozycję implementacji jednego z dwóch opisanych modeli budżetu partycypacyjnego. Jego celem jest przedstawienie możliwości

\footnotetext{
${ }^{8}$ Zob.: B. de S. Santos., Participatory budgeting in Porto Alegre: Toward a redistributive democracy, „Politics \& Society” 1998, Vol. 26, No. 4, s. 461-510.

${ }^{9} \mathrm{http}: / /$ budzet.dlalodzi.info/jak-to-dziala (dostęp: 20.08.2016).
} 
Mateusz Radziszewski - Partycypacja budżetowa...

rozwoju społeczeństwa obywatelskiego na Ukrainie w wymiarze funkcjonowania samorządu lokalnego. Należy tu przede wszystkim wskazać na to, jak budżet partycypacyjny wpływa na świadomość i aktywność lokalnych społeczności. Dlatego hipotezą, która w ramach niniejszej pracy zostanie zweryfikowana będzie:

\section{H1: Budżet obywatelski wpływa na skalę oraz intensyw- ność aktywności obywatelskiej lokalnych wspólnot.}

Obrany kierunek rozważań nie będzie jednak dotyczył emotywnego postrzegania polityki, lecz racjonalnego i roztropnego procesu współdziałania w wymiarze lokalny wspólnot obywatelskich jakimi są samorządy lokalnej. $\mathrm{W}$ analizie każdego $\mathrm{z}$ nich pomocnymi będą następujące pytania badawcze pozwalające na precyzyjną analizę wpływu budżetu partycypacyjnego na poziom społeczeństwa obywatelskiego. A są to:

\section{P1: Jak zaangażować ludzi do działania w sferze aktywno- ści obywatelskich?}

P2: Jak dochować należytej staranności procedur oraz uczciwości we wspólnym podejmowaniu decyzji?

\section{P3: Jak mierzyć efekty działalności obywatelskiej?}

Powyższe pytania stanowią matrycę dla analizy obu modeli partycypacji budżetowej w perspektywie ich implementacji w ukraińskiej przestrzeni samorządowej. Nie chodzi tu jednak o rozwiązania instytucjonalne, czy prawne, gdyż te podlegają ciągłej ewolucji i gdy zajdzie potrzeba, z pewnością będą mogły zostać należycie dostosowane. Kwestią istotniejszą jest przygotowanie kompetencyjne oraz zebranie doświadczeń przez mieszkańców Ukrainy w zakresie aktywności obywatelskich. Wiąże się to z obawami, czy jest możliwe stworzenie społeczeństwa obywatelskiego na Ukrainie? Czy prezentowane rozwiązania, jak wiele innych będą dobrze przyjęte na Ukrainie z uwagi na ich historię oraz tradycje obywatelskie? Czy budżet partycypacyjny będzie należycie odporny na problemy korupcji oraz oligarchizacji 
władzy? Krokiem w stronę znalezienia rozwiązania dokonanie analizy obecnego stanu społeczeństwa obywatelskiego na Ukrainie.

\subsection{Ukraina jako przestrzeń rozwoju społeczeństwa obywatelskiego}

Ukraina to bardzo młody kraj, który swoją państwowością cieszy się zaledwie od kilkudziesięciu lat ${ }^{10}$. Tak krótki czas istnienia i wewnętrznej konsolidacji państwa rodzi wiele problemów. Pierwszym z nich jest brak silnej tożsamość obywateli Ukrainy, która od wieków była rozdzierana pomiędzy różne mocarstwa i wcielana w przestrzeń kulturowo-cywilizacyjną raz wschodnią, a raz zachodnią ${ }^{11}$. Należy pamiętać o tym, że obecny obszar tego państwa, to historyczna arena walk, powstań oraz politycznego terroru ${ }^{12}$. Ukraina nie miała nigdy okazji nauczyć się własnej państwowości. Tym samym w perspektywie długiego trwania, nie posiada ona wystarczających doświadczeń w kreowaniu aktywności obywatelskiej. Wszystkie tego rodzaju akty, jak pokazują ostatnie lata, nie były wynikiem ewolucyjnych przemian, lecz elementem rewolucyjnego buntu przeciwko znienawidzonej władzy.

Kluczowym problemem analizy rozwoju społeczeństwa obywatelskiego na Ukrainie jest jej historia. Porównując tą sytuację do krajów azjatyckich lub Ameryki Południowej, które posiadają w swoich dziejach długie okresy prawicowych rządów autorytarnych zauważmy, że o ile w ich przypadku rządzący utrzymywali swoją stałą koncentrację

\footnotetext{
10 Ukraina proklamowała swoją niepodległość od Związku Socjalistycznych Republik Radzieckich (ZSRR) 24 sierpnia 1991 roku.

${ }^{11}$ Obszar współczesnej Ukrainy to teren ścierania się interesów Rosji i Zachodniej Europy, dlatego też sprawy ukraińskie były od zawsze determinowane polityką międzynarodową. Początki jej państwowości to proklamacja Ukraińskiej Republiki Ludowej 22 stycznia 1918. Nie istniała ona jednak zbyt długo, gdyż już 11 czerwca 1920 została zaanektowana przez Rosję Radziecką. Kolejne lata, nie zmieniły takiego stanu rzeczy i Ukraina do 1991 roku pozostawała pod władzą sowietów i wpływem ideologii komunistycznej.

${ }^{12}$ A. Chodubski, Ukraina a procesy przemian europejskich. Przeszłość i teraźniejszość, „Eastern Review” 2014, T. 3, s. 27.
} 
na utrzymaniu władzy, o tyle lewicowi ideolodzy z ZSRR mieli w swych zamysłach sformatowanie umysłów obywateli w kierunku materializmu historycznego i dialektycznego. W efekcie społeczeństwa państw krajów postsowieckich nie wykazują znaczących pokładów kapitału społecznego oraz nie posiadają doświadczeń funkcjonowania $\mathrm{w}$ ramach społeczeństwa obywatelskiego. Można zatem powiedzieć, że są one wyjałowione $\mathrm{z}$ wszelakich przejawów świadomości obywatelskiej ${ }^{13}$. Efektem tego jest dzisiejszy brak doświadczeń, czy nawet wspomnień o własnej podmiotowości, z których współczesne społeczeństwo mogłoby czerpać, wpływając na własną świadomość oraz politykę wewnętrzną państwa. Od kilkunastu lat zauważalna jest jednak znacząca przemiana mentalnościowa Ukraińców. Jednym z przejawów tego, że rozwój społeczny wyprzedził zmiany strukturalne państwa była Pomarańczowa Rewolucja z 2004 roku. Wtedy to obywatele wyszli na ulice, aby sprzeciwić się bezkarności władzy i fałszowaniu wyborów. Efektem tej pokojowej rewolucji był nowy rząd na czele z premier Julią Tymoszenko i nową głową państwa Wiktorem Juszczenko. Ich zadaniem było zreformowanie państwa, a celem strategicznym wstąpienie, w niedalekiej przyszłości, w poczet członków Unii Europejskiej. Niestety rządzący zawiedli pokładane w nich nadzieje, a w kolejnych wyborach, w 2010 roku, władze przejął prorosyjski polityk Wiktor Janukowycz ${ }^{14}$. Należy jednak pamiętać, że zmiany na najwyższych szczeblach władzy nie zmieniły uprzednio wyartykułowanych aspiracji ukraińskiego społeczeństwa. Zostały one jeszcze wzmocnione po odbywających się w Polsce i na Ukrainie Mistrzostwach Europy (Euro 2012). Szereg inwestycji w największych miastach Ukrainy, ogromna liczba turystów oraz mediów z Europy Zachodniej uświadomiły Ukraińcom, że istnieje szansa na zreformowa-

13 M. Kacewicz, Nowa wojna oligarchów na Ukrainie, „Newsweek” 2015, http://swiat.newsweek.pl/oligarchowie-rzadza-ukraina,artykuly,359789,1.html (dostęp: 22.01.2016).

${ }_{14}$ Opinia Europejskiego Komitetu Ekonomiczno-Społecznego w sprawie sytuacji ukraińskiego społeczeństwa obywatelskiego $w$ kontekście europejskich aspiracji Ukrainy, REX/403, Bruksela 2014. 
nie kraju, a w sferze społecznej mają oni prawo żyć i korzystać ze swych wolności, tak jak ma to miejsce w Unii Europejskiej. Niestety były to tylko pozory stworzone na czas trwania zawodów. Kilka lat później wydarzenie, którego efektem było powstanie tzw. Euromajdanu, zapoczątkowało falę trwających do dziś przemian. Chodzi tu o szczyt Partnerstwa Wschodniego w Wilnie, który miał być miejscem podpisania przez Janukowycza umowy stowarzyszeniowej Ukrainy z UE, aktu potwierdzającego polityczne aspiracji Ukraińców. Tymczasem nieoczekiwanie ówczesny rząd ukraiński oświadczył, że wstrzymuje przygotowała do podpisania porozumienia, a społeczeństwo po raz kolejny poczuło się oszukane i wyszło na ulicę zamanifestować swój sprzeciw. Efektem krwawy starć na Placu Niepodległości w Kijowie było obalenie rządu Janukowycza oraz nowe wybory proeuropejskich polityków: Petra Poroszenki na stanowisko prezydenta kraju oraz powołanie Arsenija Jaceniuka na premiera rządu Ukrainy.

Zarys wydarzeń minionych kilkunastu lat pokazuje, że w społeczeństwie ukraińskim narodziła się silna potrzeba zmian we własnym państwie ${ }^{15}$. Rozbudzona w 2004 roku wizja ucieczki na zachód, a co za tym idzie rozwój cywilizacyjny uległ stagnacji z winy rządzących. Wspomniany już Euromajdan, na przełomie 2013 i 2014 roku, po raz kolejny unaocznił politykom krajowym jak i forum międzynarodowemu ogromną determinację Ukraińców do modernizacji państwa ${ }^{16}$. Niestety negatywną konsekwencją tych wydarzeń było odrodzenie dotychczas uśpionych silnych różnic społecznych. Mianowicie, prozachodnie dążenia nie były podzielane przez ogół obywateli Ukrainy. Wschodnia część kraj, która posiada silne kontakty gospodarcze, a nawet rodzinne $\mathrm{z}$ Rosją nie chciała zmian, obawiając się o własny byt. Skutkiem czego Ukraina została rozerwana na dwie części w wy-

${ }^{15}$ Sytuację pogorszył również kryzys ekonomiczny, którego efektem był spadek poziomu życia na Ukrainie w 2010 roku Koszt zapewnienia minimum życiowego stał się większy niż w USA, czy w Polsce, zob. M. Krauski, Społeczeństwo obywatelskie na Ukrainie, http://www.forum-ekonomiczne.pl/article/spoleczenstwo-obywatelskiena-ukrainie/\#.VqTDbfnhCHs (dostęp: 25.01.2016).

16 Ibidem. 
Mateusz Radziszewski - Partycypacja budżetowa...

miarze społecznym i politycznym, które w przyszłości, nawet po zakończeniu działań zbrojnych, będzie niezwykle trudno scalić.

Kontując rozważania na temat przestrzeni rozwoju społeczeństwa obywatelskiego na Ukrainie należy wziąć pod uwagę poziom życia przeciętnych Ukraińców. Z informacji jakie dostarcza Instytut Wschodni wynika, iż sytuacja jest bardzo poważna, a problem stale narasta. Koszt utrzymania na Ukrainie jest dużo większy niż w USA, a nawet w Polsce ${ }^{17}$. Ukraińcy nie widzą szans na własny rozwój, czy chociaż zapewnienie bytu rodzinie w kraju, dlatego znaczący odsetek osób opuszczających swoją ojczyznę to ludzie poszukujący pracy lub próbujący swoich sił na uczelniach zagranicznych ${ }^{18}$. Kierunkiem jaki obierają są kraje Unii Europejskiej oraz Rosja, co stanowi jeden z dowód na przedstawione uprzednio silne rozwarstwienie społeczne ${ }^{19}$. Wspomniany problem braku perspektyw odznacza się również w przestrzeni aktywności obywatelskiej. Wielokrotnie podnoszony jest brak reakcji władz różnego szczebla na szereg protestów społecznych. Wynika to również z deficytu tradycji prowadzenia dialogu władzy z obywatelami. Rodząca się społeczna potrzeba partycypowania w sprawach ważnych dla kraju, swojego regionu, czy miasta, nie idzie $\mathrm{w}$ parze $\mathrm{z}$ adekwatną odpowiedzią polityków. Aktywizację obywatelską mieszkańców Ukrainy utrudnia również brak dostępu do mediów, które pozostają w rękach lokalnych oligarchów. Jedynym

\footnotetext{
17 Ibidem.

18 Zgodnie z danymi Państwowego Urzędu Statystycznego, średnia krajowa płaca na Ukrainie wynosi 140 dolarów (dane z 2015 roku), zob. M. Ciastocha, Ukrainiec najbiedniejszy w Europie. Sprawdź, na co go stać, „Newsweek” z dn. 31.03.2015, http://swiat.newsweek.pl/ile-zarabiaja-ukraincy,artykuly,360185,1.html (dostęp: 25.01.2016).

Dla porównania w Polsce wynosi ona 865 euro, a w Niemczech 2995 euro, zob. Niemiec zarabia trzykrotnie więcej niż Polak. »U nas jest wojna o płace«, tvn24bis. $\mathrm{pl} /$ pieniadze,79/pensje-w-polsce-i-europie-jakie-sa-roznice,562305.html (dostęp:. 25.01.2016.

${ }^{19}$ Największa liczba Ukraińców pracuje w Rosji - 500 tys. osób, O. Konsevych, Wyjechać aby przeżyć. Emigracja w krajach Partnerstwa Wschodniego, www.eastbook. eu/blog/2013/08/19/wyjechac-aby-przezyc-emigracja-w-krajach-partnerstwawschodniego (dostęp: 22.01.2015).
} 
instrumentem pluralistycznej debaty pozostaje Internet. Rodzi to jednak obawę oderwania sfery społecznej debaty od realne polityki, co może prowadzić do jej alienacji od politycznego procesu decyzyjnego $^{20}$. Oksana Romaniuk z pozarządowej organizacji Instytut Informacji Masowej w Kijowie uważa, że rewolucja jaka zaszła na Ukrainie nie objęła swoim zasięgiem środowiska mediów ${ }^{21}$. Problem komunikacji władz z obywatelami dotyczy również przepływu informacji o istotnych wydarzenia ze świata polityki. Dziennikarze zauważają, że celem polityków oraz oligarchów posiadających media nie jest reforma struktur politycznych, a jedynie utrzymanie w nich swoich wpływów. Dlatego też nie przyczyniają się oni do zwalczania korupcji oraz szeregu nadużyć w administracji publicznej. Zadanie to spoczywa jedynie na niezależnych dziennikarzach śledczych oraz aktywistach społecznych, co ukazuje negatywną tendencję i brak woli realnych przemian systemu'22.

Należy również zwrócić uwagę na stan aktywności organizacji pozarządowych na Ukrainie, gdyż sfera ta również pozostaje obiektem sporów politycznych. Z danych zebranych przez OBWE w 2013 roku na Ukrainie jest zarejestrowanych 50850 organizacji pozarządowych. Ich liczba różni się znacząco w zależności od regionu kraju i oscyluje od 200 w Iwano-Frankowsku do 5 tys. w samej Odessie23. Wśród nich wiele zajmuje się kwestiami polityki lokalnej oraz rozwoju społeczeństwa obywatelskiego, jednakże ich postrzeganie w opinii samych Ukraińców jest różne. Część z nich po rewolucji na Majdanie aktywnie bierze udział w promowaniu prozachodnich standardów. Niestety są

${ }^{20}$ No Revolution Here: News Media In Ukraine Remain In Same Hands, www.kyiv post.com/article/content/ukraine-politics/no-revolution-here-news-media-in-ukrai ne-remain-in-same-hands-405942.html (dostęp: 25.01.2016).

21 Zob. http://imi.org.ua/en (dostęp: 25.01.2016).

${ }^{22}$ Zob.: F. Dresen, Media in Ukraine: A Domain of the State, the Oligarchs, or the Public?, https://www.wilsoncenter.org/publication/media-ukraine-domain-the-state -the-oligarchs-or-the-public\#sthash.REhdggxR.dpuf (dostęp: 25.01.2016).

${ }^{23}$ Civil Society And The Crisis In Ukraine, OECD SEC.FR/125/15/4 March 2015, s. 4, http://www.osce.org/ukraine-smm/141046?download=true (dostęp: 24.01.2016). 
Mateusz Radziszewski - Partycypacja budżetowa...

też takie, które wykazują się klientelizmem wobec lokalnych oligarchów i polityków ${ }^{24}$.

Ukraińskie społeczeństwo obywatelskie znajduje się w okresie bardzo dynamicznych przemian. Zmiany polityczne, jakie miały miejsce na szczeblu centralnym spowodowały, że Ukraińcy chętniej obserwują wydarzenia polityczne w państwie, jednocześnie angażując się w rozmaite oddolne inicjatywy. Jednym z efektów tego są coraz silniej artykułowane problemy oraz nadużycia jakie dotyczą właśnie sfery partycypacji społecznej oraz funkcjonowania państwa. Kluczowymi elementami wymagającymi naprawy są tu przede wszystkim:

- podniesienie transparentności sfery organizacji pozarządowych (jako tej będącej płaszczyzną artykulacji interesów i podejmowania dyskusji na temat ważnych problemów przez ukraińskie społeczeństwo);

- wzmocnienie zaangażowania obywateli w sferze publicznej (zwiększenie dostępu obywateli do informacji publicznej, co obecnie podejmowane jest na poziome debaty w ramach rozwoju konsultacji społecznych);

- zbudowanie płaszczyzny zaufania między obywatelami, a władzami (przeciwdziałanie korupcji i klientelizmowi struktur władz);

- znaczne nasilenie relacji między podmiotami społecznymi, a administracją publiczną;

- promocja dobrego rządzenia poprzez stworzenie odpowiednich ram prawnych dla efektywniejszego świadczenia usług publicznych;

- umożliwienia szerokiej partycypacji społecznej w procesie decyzyjnych na szczeblu władz lokalnych i krajowych.

24 Opinia Europejskiego Komitetu Ekonomiczno-Społecznego w sprawie sytuacji ukraińskiego społeczeństwa obywatelskiego $w$ kontekście europejskich aspiracji Ukrainy, REX/403 Bruksela, 16 października 2014, http://eur-lex.europa.eu/legal-content /PL/TXT/?uri=CELEX\%3A52014IE3088 (dostęp: 25.01.2016). 
W każdym z tych obszarów budżet partycypacyjny może stać się instrumentem pożytecznym zarówno dla władz jak i obywateli. Ponadto, zaprezentowane modele rozwoju demokratycznych struktur państwa znacząco mogą się przyczynić do poprawy jakości społeczeństwa obywatelskiego na Ukrainie. Dlatego też w dalszej kolejności należy przedstawić ofertę rozwiązań jakie oferuje każdy z wymienionych modeli budżetowych.

\section{Klasyczny model budżetu partycypacyjnego}

Brazylia nigdy nie była krajem uchodzącym za przykład stabilności politycznej oraz rozwiniętego społeczeństwa obywatelskiego. Jednakże nie przeszkodziło jej to w wypracowaniu nowego rewolucyjnego instrumentu partycypacji społecznej, który obecnie jest znany i ceniony na całym świecie. Idea brazylijskiego budżetu partycypacyjnego powstała w 1989 roku i od tego momentu zyskała miano podstawowego narzędzia aktywizującego społeczeństwo ${ }^{25}$. Praprzyczyną, z powodu której mogła ona ujrzeć światło dzienne był proces tranzycji systemowej, który z końcem lat 80. zamknął krwawy rozdział w historii Brazylii. Był to koniec wieloletnich rządów prawicowej dyktatury wojskowej, skorumpowanej i mocno skompromitowane w oczach społeczeństwa, której działania ostro zwalczające wszelkie akty nieposłuszeństwa obywateli, mocno udręczyły społeczeństwo ${ }^{26}$. Władzę w państwie stopniowo zaczęła przejmować lewica, a w samym Porto Alegre na fotel burmistrza wybrany został działacz zwiążkowy związany z ugrupowaniem Partidos de Trabajadores, Olivio Dutra. Przejmowanie władzy przez dotychczasowy opozycjonistów nie było jednak tak proste, gdyż nowy włodarz miasta, z powodu nieuzy-

25 Zob. B. Gianpaolo, Militants and Citizens. The Politics of Participatory Democracy in Porto Alegre, Stanford 2005.

26 C. Souza, Participatory budgeting in Brazilian cities: limits and possibilities in building democratic institutions, „Environment \& Urbanization” 2001, Vol 13, s. 161, http://www.ucl.ac.uk/dpu-projects/drivers_urb_change/urb_governance/pdf_part_ budg/IIED_Souza_Budgeting_Brazil.pdf, 11.11.2015. 
Mateusz Radziszewski - Partycypacja budżetowa...

skania wystarczającej większości w radzie miasta (Câmara Municipal de Porto Alegre), nie mógł samodzielnie realizować swojego programu wyborczego ${ }^{27}$. Wyjściem z tej sytuacji było zaangażowanie mieszkańców w proces decyzyjny, który da silny mandat społeczny burmistrzowi, a członków organu kolegialnego postawi w krępującej sytuacji, w której nie będą mogli się przeciwstawić głosom obywateli28.

Klasyczny model budżetu partycypacyjnego z Porto Alegre opiera się na prowadzeniu licznych konsultacji społecznych przedstawicieli władz miasta $\mathrm{z}$ reprezentantami mieszkańców. Mechanizm ich funkcjonowania jest dość skomplikowany, a układ wysoce zhierarchizowany. Przedstawiciele mieszkańców są wybierani w trójstopniowej strukturze. Zebraniem najniższego szczebla w Porto Alegre jest zgromadzenie osiedlowe, którego zadaniem jest wybrać swoich delegatów do rad dzielnic ${ }^{29}$. Na tym etapie tworzone są zhierarchizowane listy propozycji inwestycyjnych. Początkowo członkowie rad dzielnic pełnili swoją funkcję tylko jedną kadencję, lecz w późniejszym okresie już dwie. Ich praca, jak wszystkich innych delegatów różnego szczebla, jest pod stałą kontrolą mieszkańców i w każdej chwili mogą oni zostać odwołani. Najwyższym organem w tej strukturze jest Rada Budżetu Partycypacyjnego, której członkowie sprawują swoją funkcję przez okres dwóch rocznych kadencji ${ }^{30}$. W debatach nad nowopowstającym budżetem uczestniczą eksperci, którzy wspierają mieszkańców swą wiedzą. Oprócz tego odbywają się oficjalne wizytacje miejsc potencjalnych inwestycji w celu jak najlepszego zbadania sprawy oraz podjąć właściwej decyzji. Kluczową role w tym modelu budżetu partycypacyjnego odgrywają liderzy opinii publicznej, potocznie zwani „spo-

27 B. de S. Santos, Participatory budgeting in Brazilian cities: limits and possibilities in building democratic institutions, „Environment \& Urbanization” 2001, Vol 13, No. 1., s. 171.

28 Zob. G. Baiocchi, Participation, activism, and politics: The Porto Alegre experiment and deliberative democratic theory, „Revised” 1999, No. 11, Wisconsin: University of Wisconsin - Madison 1999.

29 W. Kębłowski, Budżet partycypacyjny, krótka instrukcja obsługi, Warszawa 2013, s. 10 .

30 B. de S. Santos, Participatory..., op. cit., s. 461-510. 
łecznikami", znający problemy mieszkańców ${ }^{31}$. To w dużej mierze oni zasilają szeregi Rady Budżetu Partycypacyjnego i to ich zadaniem jest przygotowanie dokumentu z propozycjami budżetowymi, a następnie zaprezentowanie go urzędnikom miejskim, a co za tym idzie przekonanie ich do podjęcia decyzji zgodnych z wolą mieszkańców. Ponadto kompromisowy projekt budżetu miasta z punktu widzenia społeczeństwa nie podlega zmianom. Jedynie burmistrz może zawetować jego część lub odesłać projekt do komisji32.

Niestety debaty w ramach zgromadzeń nie zawsze mogą być należycie merytoryczne, gdyż na najniższym poziomie może brać w nich udział nawet do 1000 osób. Znacznie ogranicza to możliwość przedstawienia własnych postulatów i uniemożliwia realną partycypację. Niefunkcjonalny sposób organizacji zebrań powodował, że głos obywateli wielokrotnie stawał się rozczłonkowany między różnymi grupami społecznym, a więc mniej skuteczny.

Nie ulega wątpliwości, że klasyczny model budżetu partycypacyjnego z Porto Alegre powstał na kanwie rywalizacji politycznej lokalnych działaczy rywalizacyjnych ze sobą partii politycznych. To jednak nie przeszkodziło $w$ tym, aby stać się istotnym instrumentem rozwijających relacje społeczne oraz świadomość obywatelską mieszkańców. Budżet partycypacyjny stał się niejako platformą debaty dla różnych grup społecznych powodując zwiększenie lokalnej kohezji społecznej, wytworzenie atmosfery dialogu i potrzeby porozumienia, a także ucząc Brazylijczyków dochodzenia do konsensusu.

\footnotetext{
${ }^{31}$ Należy pamiętać, że budżet obywatelski zakłada udział w procesie decyzyjnym wszystkich grup społecznych, bez względu na majętność, czy wykształcenie.

32 Szczegóły procesu uchwalania budżetu partycypacyjnego w Porto Alegre: Prefeitura de Porto Alegre. Orçamento Participativo, http://www2.portoalegre.rs. gov.br/op/\#, (dostęp: 11.11.2015).
} 
Mateusz Radziszewski - Partycypacja budżetowa...

Rysunek nr 1. Schemat funkcjonowania Budżetu obywatelskiego w Porto Alegre

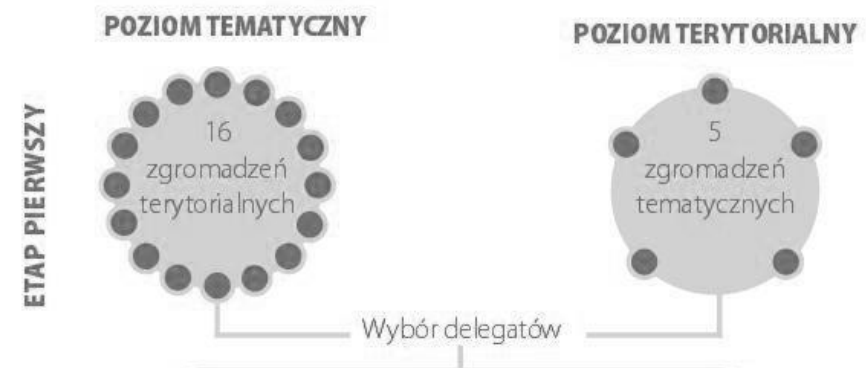

Tematyczne i terytorialne fora delegatów

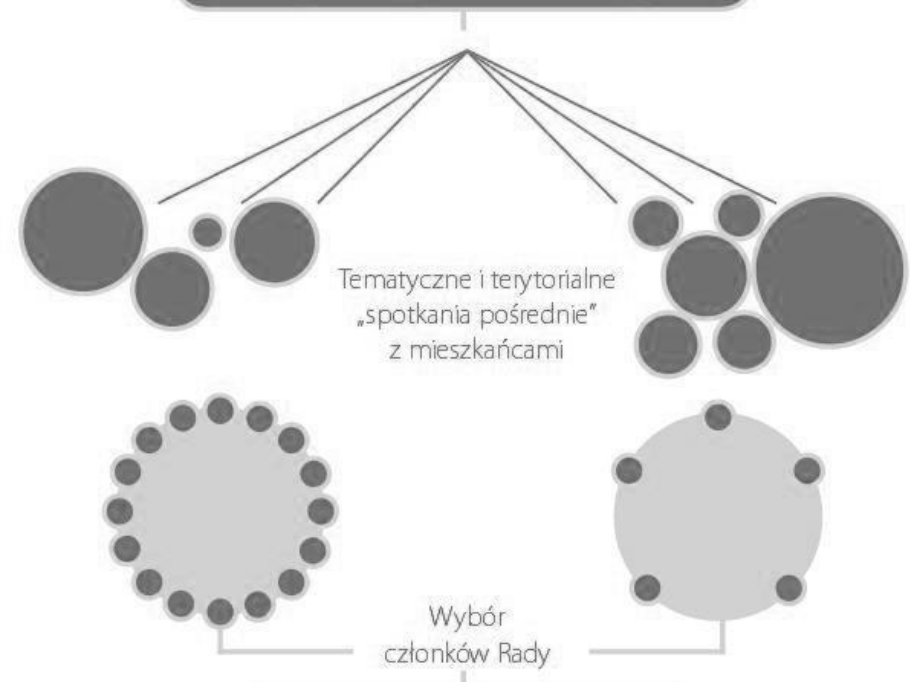

Rady Budżetu Partycypacyjnego

Źródło: Na podstawie: R. Górski, Bez państwa, Warszawa 2007, s. 6; http://otworzksiazke.pl/images/ksiazki/bez_panstwa/bez_panstw. pdf, [za:] W. Kłębowski, Budżet partycypacyjny, krótka instrukcja obsługi, Warszawa 2013, s. 30. 
Należy zatem stwierdzić, że powyżej zaprezentowany model budżetu partycypacyjnego wpływa zarówno na skalę oraz intensywność aktywności obywatelskiej lokalnych wspólnot. Jednakże oddziaływanie to nie jest równomierne, gdyż jak zostało wcześniej wykazane, to liderzy opinii społecznej lub tzw. „społecznicy” odgrywają tu najistotniejszą rolę, będą powiernikami różnych grup społecznych. W efekcie to oni zabierają głos w procesie tworzenia budżetu, tym samym działając w zastępstwie dla licznej grupy mieszkańców, którzy z racji zhierarchizowanego układu mechanizmu budżetowego nie mają takiego samego wpływu na ostateczny kształt budżetu miasta. Na usprawiedliwienie tego zjawiska warto przywołać słowa burmistrza Porto Alegre Oliwio Dutry, który stwierdził, że gdyby brali w nim udział wszyscy byłoby to sprzedawanie iluzji „bezpośredniej demokracji na greckim placu, która nie była demokracją wszystkich, ale demokracją najlepszych"33. Tego powodu klasyczny model budżetu partycypacyjnego z Porto Alegre jednoznacznie można określi jako przykład demokracji przedstawicielskiej.

Budżet partycypacyjny w Porto Alegre nawet kilka lat po swojej premierze był dobrze oceniany przez mieszkańców. W badaniach z 1995 roku, aż 56,5\% biorących w nim udział stwierdziło, że odczuwało satysfakcję z prac nad budżetem i efektów jego funkcjonowania $^{34}$. Należy zatem stwierdzić, że aby zaangażować ludzi do działania w sferze publicznej należy pracować nad ich świadomością podmiotowości, tak aby obywatele mogli stać się kolektywnym i aktywnym aktorem na scenie politycznej. Należy przy tym dochować staranności oraz uczciwości procedury budżetowej. W przypadku brazylijskiego modelu rozwiązano to $\mathrm{w}$ taki sposób, że to mieszkańcy regulują to sami. To od nich zależy jakie tematy będą podejmowane $w$ trakcie spotkań rad; co będzie się z nimi działo (tzn. czy będą realizowane,

\footnotetext{
${ }^{33}$ S. Sánchez, E. Aragonès, A Model of Participatory Democracy: Understanding the Case of Porto Alegre, Edinburgh 2004, s. 2.

34 B. de S. Santos, Participatory..., op. cit., s. 170.
} 
Mateusz Radziszewski - Partycypacja budżetowa...

czy uzna się je za mniej istotne) i wreszcie kto w ich imieniu będzie pracował na kolejnych szczeblach piramidy partycypacji budżetowej.

Odnosząc się do efektów tejże działalności obywatelskiej należy stwierdzić, że w sferze inkluzji społecznej model klasycznego budżetu partycypacyjnego nie uzyskał znaczących rezultatów. Zaangażowanie społeczne w proces jego tworzenia oscylowało w okolicach kilku procent, co jest efektem utrudnionego udziału dostępu do z powodu hierarchicznego systemu zależności. Nie ulega jednak wątpliwości, że więzi społeczne wytworzone między osobami uczestniczącymi w procesie tworzenia budżetu pozwoliły na ustanowienie nowych standardów prowadzenia polityki poprzez dialog i współpracę, co pozytywnie wpłynęło na lokalny wymiar społeczeństwa obywatelskiego.

\section{Fundusz komunalny jako element demokracji bezpośredniej}

Pierwszy raz pomysł na stworzenie instrumentu partycypacji społecznej inspirowanego brazylijskim budżetem miał miejsce w Płocku, gdzie w latach 2003-2005 organizowano „fundusz grantowy”, zwany również public/private negotiation table, którego zadaniem było wsparcie lokalnych organizacji pozarządowych ${ }^{35}$. Ten jednak nie uzyskał wyraźnego poparcia wśród polskich samorządowców. Budżet partycypacyjny swój prawdziwy początek w naszym kraju miał dopiero w 2011 roku, kiedy to miasto Sopot zorganizowało pierwszą edycję tzw. „Budżetu obywatelskiego”. Zaraz po nim kolejni włodarze miast postanowiły wdrożyć ten instrument partycypacji społecznej w swoich samorządach. Na kanwie krajowych trendów rozwoju partycypacji społecznej, pomysł budżetu partycypacyjnego postanowili wykorzystać również łódzcy samorządowcy. Pierwsze propozycje jego implementacji pojawiły się po lewej stronie sceny politycznej, ale to rządząca od 2010 roku centrowa Platforma Obywatelska postanowiła wcielić go w życie. Władze Łodzi, argumentując zorganizowanie budżetu obywatelskiego, podkreślały jego walor edukacyjny, traktując go jako

35 W. Kębłowski, Budżet partycypacyjny..., op. cit., s. 4. 
mechanizm rozwoju świadomości oraz aktywności obywatelskiej, mniejszą uwagę przykładając do jego efektów ekonomicznych.

W celu zorganizowania pierwszej edycji w 2013 roku powołano specjalny zespół złożony z radnych i urzędników miejskich, których zadaniem było jego zaplanowanie i przeprowadzenie ${ }^{36}$. W tym przypadku seria spotkań z mieszkańcami w ramach konsultacji społecznych poprzedziła całą procedurą budżetową, a nie jak w Brazylii była jej integralną częścią. Niestety w przeciwieństwie do pierwowzoru, w polskim prawodawstwie brak jasnych ram wdrażania budżetów partycypacyjnego, skutkiem czego ich funkcjonowanie sankcjonuje art. 5a Ustawy o samorzq̨dzie gminnym, który mówi: „W wypadkach przewidzianych ustawą oraz w innych sprawach ważnych dla gminy mogą być przeprowadzane na jej terytorium konsultacje z mieszkańcami gminy"37. Dlatego też jak stwierdził jeden z łódzkich radnych: „budżet obywatelski to umowa dżentelmeńska między prezydentem, Radą Miejską a łodzianami" ${ }^{38}$. Uzasadnione są więc obawy, że w przypadku tego modelu wszelkie perturbacje polityczne mogą spowodować, brak realizacji części projektów obywatelskich lub całkowite zerwanie z ideą budżetu partycypacyjnego w przyszłości.

„Budżet Obywatelski dla Łodzi” zakłada przeznaczenie 1\% budżetu miasta na projekty, które mają zostać zgłoszone i wybrane przez samych mieszkańców ${ }^{39}$. Zadania jakie mogą zostać poddane pod głosowanie muszą być zgodne z kompetencjami miasta ${ }^{40}$. Po stronie pomy-

36 Zob. http://www.dzienniklodzki.pl/artykul/713381,lodzianie-beda-miec-wplywna-budzet-obywatelski,id,t.html (dostęp: 11.11.2015).

37 Ustawa z dnia 8 marca 1990 r. o samorzadzie gminnym, Dz. U. $1990 \mathrm{Nr} 16$ poz. 95.

38 Zob. Protokół nr 24/IX/2013, posiedzenia Doraźnej Komisji ds. Budżetu Obywatelskiego Rady Miejskiej w Łodzi z 3 września 2013 r., http://bip.uml.lodz.pl/_plik. php?id=34826\&PHPSESSID= (dostęp: 19.01.2015).

${ }^{39}$ Zob. http://budzet.dlalodzi.info (dostęp: 20.08.2016).

${ }^{40}$ Warto podkreślić, iż zgodnie z przyjętą zasadą, Rada Miejska w Łodzi po przeprowadzeniu głosowania nad projektami do BO zobowiązuje się przegłosować zwycięskie z nich pozytywnie, a następnie Prezydent zobowiązuje się do ich wykonania. Również zgodnie $\mathrm{z}$ tą zasadą, władza wykonawcza ma kolejny roku budżetowy na dokonanie danej inwestycji, jednakże skala inwestycji może sprawić, iż czas ten 
słodawców leży obowiązek opisania projektu, przedstawienia wstępnego kosztorysu inwestycji, a także zebrania 15 podpisów pod swoim pomysłem. Wreszcie, wszystkie propozycje zostają uszeregowane w dwie kategorie. Dotychczas były to: zadania ogólnomiejskie i dzielnicowe, jednakże od 2016 roku, IV edycji Budżetu Obywatelskiego dla Łodzi, zadania zostały skategoryzowane na: ponadosiedlowe i osiedlowe, gdyż uznano, że osiedla, z racji zajmowania mniejsze powierzchni są bliższe koncepcji lokalnych wspólnot, a zatem mieszkańcy łatwiej się z nimi utożsamiają, niż z wielkimi i wysoce anonimowymi społecznie dzielnicami miasta ${ }^{41}$.

Ostateczny wybór zadań z budżetu partycypacyjnego należy do Łodzian. Jedynym kryterium, które należy spełnić, aby wziąć udział w głosowaniu na zadania z budżetu obywatelskiego to najpóźniej w dniu wyborów ukończyć 16 roku życia. Wybory odbywają się za pośrednictwem Internetu oraz specjalnych kart do głosowania rozlokowanych $\mathrm{w}$ instytucjach samorządowych $\mathrm{w}$ całym mieście. Trwają kilka, a nawet kilkadziesiąt dni, co umożliwia wszystkim mieszkańcom Łodzi w dogodnym czasie wziąć w nich udział. Łodzianie w ramach procedury wyborcze decydują o wyborze: do 5 zadań ogólnomiejskich (od 2016 ponadosiedlowych) i do 5 zadań dzielnicowych (od 2016 osiedlowych $)^{42}$. Suma jaką władze miasta przeznaczały na zadania $\mathrm{z}$ budżetu obywatelskiego zmieniała się w czasie, lecz od kilku lat jest to $40 \mathrm{mln} \mathrm{zt}^{43}$. Zmianie ulega jedynie jej rozkład, który obecnie jest następujący: 9,5 mln zł na zadania ponad osiedlowe oraz 30,5 mln zł podzielone pomiędzy wszystkie osiedla w mieście, zgodnie z parytetem liczby mieszkańców przypadających na każde z nich ${ }^{44}$.

zostanie wydłużony przez samo miasto, np. projekt roweru miejskiego. Zob. http://wrower.pl/miasto/rower-miejski-w-lodzi-lodzki-rower-publiczny,3313.html (dostęp: 11.11.2015).

${ }^{41}$ Głosować na projekty obywatelskie mogły osoby, które w dniu wyborów ukończyły 16 rok życia.

42 W kolejnych edycjach budżetu w 2014 i 2015 roku kwota ogólna została zwiększona do $40 \mathrm{mln}$ zł: $10 \mathrm{mln}$ zł na zadania ogólne oraz $6 \mathrm{mln}$ zł dla każdej z dzielnic.

${ }^{43}$ W I edycji Budżetu Obywatelskiego dla Łodzi było to 20 mln zł.

44 Zob. http://uml.lodz.pl/budzet_obywatelski/2017 (dostęp: 20.09.2016). 
Rysunek nr 2. Schemat funkcjonowania Budżetu obywatelskiego dla Łodzi

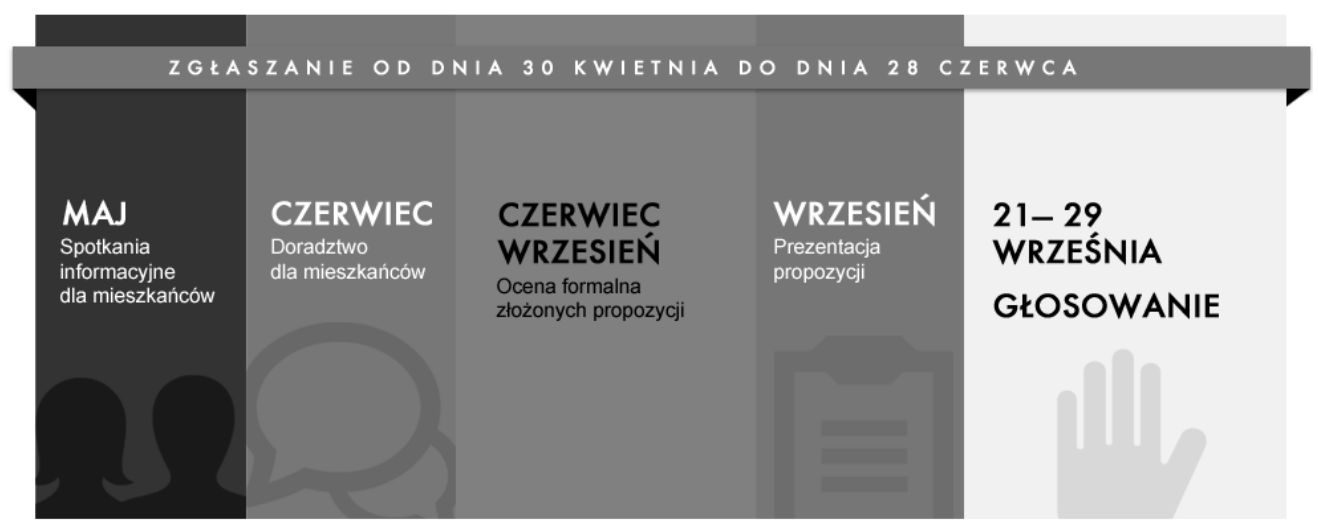

Źródło: http://budzet.dlalodzi.info (dostęp: 12.01.2016).

Problemy wynikające $\mathrm{z}$ pierwszych dwóch edycji Budżetu Obywatelskiego dla Łodzi zmusiły twórców projektu do zmian regulaminowych. Władze Łodzi ogłosiły wprowadzenie nowych reguł sankcjonujących III edycję budżetu partycypacyjnego. Polegały one na tym, że wartość każdego z projektu nie mogła przekroczyć 25\% środków przeznaczonych na danych obszar: dzielnicę lub ogólnomiejskie. Ponadto projektodawcy musieli wykazać, że ich pomysł będzie służył szerszej grupie osób, a nie tylko zamkniętym ośrodkom, instytucją takim jak np. szkoła. Miało to zapobiec tworzeniu się enklaw, odseparowanych społecznie od pozostałej części miasta. Następnie ustalono, że pod tym samym adresem, może być zrealizowany tylko jeden projekt, co niweluje monopol tzw. silnych odseparowanych od reszty miasta ośrodków z dużym kapitałem społecznym. Sama procedura głosowania również została ulepszona, dzięki nowemu wzorowi karty do głosowania, a dodatkowo każdy oddany głos przez Internet musiał być potwierdzony SMS-em na telefon głosującego ${ }^{45}$. Zmiany te nie ule-

\footnotetext{
${ }^{45}$ Należy również dodać, że władze miasta w celu dalszej modernizacji łódzkiego budżetu powołały do życia organ pod nazwą Rada Programowa ds. Budżetu Obywa-
} 
Mateusz Radziszewski - Partycypacja budżetowa...

gły zmianie, gdy postanowiono wprowadzić nowy obszar głosowania, czyli osiedla.

Łódzki budżet partycypacyjny pozwolił również na ukazanie praktycznego wymiaru partycypacji społecznej. W pierwszej kolejności ujawnił istotne pokłady kapitału społecznego osób zorganizowanych wokół instytucji publicznych takich jak szkoły oraz miejskie przychodnie zdrowia. Ponadto wykazała, że mieszkańcy dużych osiedli mieszkalnych mają duży potencjał mobilizacyjny i integracyjny. Ostatnią grupą odznaczającą się wysokim poziomem aktywności były organizacje pozarządowe, w szczególności skupione w ramach ruchów miejskich oraz cyklistów. Wyniki następujących po sobie kolejnych edycji budżetu pokazują zmienne tendencje $\mathrm{w}$ preferencjach mieszkańców Łodzi. W pierwszej najczęściej wybierane projekt dotyczyły infrastruktury, w szczególności drogowej. Domeną kolejnej były inwestycje w łódzkich szkołach, a ostatniej zieleń miejska i rekreacja. Warto również zwrócić uwagę na to, że na przestrzeni trzech lat Łodzianie nauczyli się korzystać z nowego instrumentu partycypacji. Na początku istnienia budżetu partycypacyjnego projekty, które zdobywały największą ilość głosów były bardzo duże i drogie, skutkiem czego sumaryczna pula wszystkich wykonanych przedsięwzięć była mała. Edycja z 2015 roku ukazała, że wśród zwycięskich pomysłów dominowały te nieco tańsze, co umożliwiło wykonanie większej puli projektów, a zatem zaspokojenie potrzeb większej liczby osób z różnych środowisk, posiadających różne potrzeby.

Jak można zauważyć budżet partycypacyjny istotnie wpływa na skalę oraz intensywność aktywności obywatelskiej lokalnych wspólnot. Nie należy oczekiwać jedynie pozytywnego trendu w tej sferze, gdyż uruchomienie pewnych procesów $\mathrm{w}$ tkance społecznej powoduje również ujawnienie się, dotychczas uśpionych, różnic społecznych, które powodują napięcia społeczne, dysharmonizując lokalną wspólnotę. Nie oznacza to również, że aktywizacja społeczna nie powinna

telskiego. Zob. http://budzet.dlalodzi.info/budzet-obywatelski-na-2016-zmiany-wzasadach (dostęp: 11.11.2015). 
mieć miejsca, aby „nie obudzić złych demonów”. Chodzi tu przede wszystkim o to, aby lokalne społeczności uczyły żyć ze sobą w pokoju oraz, gdy zajdzie potrzeba integrować się, zrzeszać, współpracować. Łódzki przykład pokazuje, że aby wpłynąć na poziom aktywności obywatelskich, wystarczy jedynie ukazać społeczeństwo korzyści jakie płyną z tej działalności. Kiedy jednej grupie społecznej uda się zintegrować i zdobyć wystarczająco dużą liczbę głosów, aby ich projekt budżetowy został zrealizowany, inne środowiska, idąc za przykładem tych pierwszy, również będą upatrywać w budżecie partycypacyjnym potencjalnych korzyści, a zatem mobilizować się, integrować i współpracować. Sporną kwestią pozostaje jednak to, jak dochować należytej staranności i przejrzystości procedur budżetowych. Łódzki przykład pokazał, że dzielnicowy poziom wybierania zadań jest nieefektywny, gdyż występuje znacząca dominacja jednych osiedli nad drugimi. Skutkiem czego regulamin Budżetu Obywatelskiego dla Łodzi został zmieniony, a na efekty będziemy musieli poczekać co najmniej do czasu sporządzenia przez urzędników łódzkiego magistratu raportu z przeprowadzenia IV edycji Budżetu Obywatelskiego dla Łodzi 2017.

Na koniec należy zastanowić się nad tym, co powinno zostać uznane za sukces tego modelu budżetu partycypacyjnego. Czy są nim wybrane w głosowaniu projekty? A może liczba osób uczestnicząca w samej procedurze wyborów. Niestety dotychczasowa frekwencja podczas wcześniejszych edycji budżetu nie była zbyt duża jak na możliwości jakie daje ten model. W pierwszej edycji Budżetu obywatelskiego dla Łodzi w 2013 roku udział wzięło ok. 129 tys. osób, w drugiej 174834 osób, a w 2015 - ok. 136 tys. osób. Warto podkreślić, że partycypować w nim mogły jedynie osoby, które ukończyły 16 rok życia. Zgodnie z danymi ze spisu powszechnego z 2013 roku w Łodzi osób w wieku powyżej 16 lat jest ok. 622 tys. ${ }^{46}$. Frekwencja zatem oscylowała w granicach 21\% w 2013, 28\% w 2014 i 22\% w 2015. W tym przypadku trudno jednoznacznie udzielić odpowiedzi. Pytanie

\footnotetext{
${ }^{46}$ Ludność - dane o Łodzi 2014, http://lodz.stat.gov.pl/dane-o-wojewodztwie/ stolica-wojewodztwa-1323/ludnosc-dane-o-lodzi-2014 (dostęp: 20.08.2016).
} 
Mateusz Radziszewski - Partycypacja budżetowa...

to wydaje się, że powinno zostać bez odpowiedzi do czasu poznania wyników IV edycji Budżetu obywatelskiego dla Łodzi, w którym poznamy odpowiedź na pytanie, czy zmniejszenie skali okręgu wyborczego wpływa pozytywnie, czy negatywnie na frekwencję wśród wyborców, w przypadku głosowania na obywatelskie projekty budżetowe.

\section{Podsumowanie}

Zaprezentowane w niniejszym artykule dwa modele tworzenia budżetów partycypacyjnych to ważne instrumenty pobudzające lokalną społeczność do aktywności. Każdy z nich robi to w nieco inny sposób, jednak zawsze partycypacja społeczna obywateli w procesie politycznym na szczeblu samorządowym zostaje wzmocniona. Wdrożenie któregoś z wymienionych modeli jako instrumentu aktywizującego społeczeństwo w miastach Ukrainy może spowodować ujawnienie się licznych problemów w sferze społecznej i politycznej. Z pewnością jednak należy stwierdzić, że hipoteza mówiąca o tym, iż budżet partycypacyjny wpływa na skalę oraz intensywność aktywności obywatelskiej lokalnych wspólnot potwierdza się zarówno w przypadku modelu brazylijskiego jak i jego łódzkiego odpowiednika.

Kluczowym problemem wdrażania instrumentów partycypacji społecznej jest zaangażowanie społeczeństwa do działania. Aktywność tą determinują różne czynniki, spośród których najważniejszymi są: doświadczenie oraz historia. Jak zatem sprawić, aby ludzie chcieli brać udział w życiu politycznym? Przede wszystkim należy propagować ideę współodpowiedzialności za otaczającą przestrzeń. Następnie niezwykle ważnym jest podnoszenie świadomości obywateli w kwestii artykulacji własnych preferencji oraz wyrażania sprzeciwu wobec działań władz. Ten ostatni element wcale nie musi oznaczać, że obecnie sprawujący władzę samemu będą przyczyniać się do utraty legitymacji politycznej. Oba modele budżetów partycypacyjnych pokazały, że najważniejszym aspektem rządzenia jest dialog. Bez względu na to 
jak bardzo będzie on żywiołowy, ile w ramach niego ujawni się problemów oraz konfliktów społecznych, nie ma nic cenniejszego dla każdego wyborcy (obywatela), jak możliwość rozmowy ze swoimi przedstawicielami w organach politycznych i świadomość, że jego głos został wysłuchany oraz stanowi ważny czynnik kształtując działania polityczne. Należy zatem wypracować taki mechanizm komunikacji władz ze społeczeństwem, aby nieustannie podtrzymywać on dialog społeczny i pozwalał wspólnie rozwiązywać bieżące problemy lokalnej wspólnoty.

Wytworzenie mechanizmów komunikacji władz z obywatelami wiąże się z pytaniem, jak dochować staranności procedur oraz uczciwości podejmowanych decyzji? W pierwszej kolejności należy stworzyć spis zasad i reguł, podpartych zapisami w prawie, które będą jednoznacznie regulować aktywność obywatelską wszystkich uczestników budżetu partycypacyjnego. Regulamin jego przeprowadzania nie może być nieustannie zmieniany, jak miało to miejsce m.in. w Łodzi. Z drugiej strony współpraca wymaga partnerskich zasad kooperacji między władzami, a obywatelami, dlatego hierarchiczna struktura budżetowa, jaką odznacza się model z Porto Alegre również nie wpływa pozytywnie na zaangażowanie się dużych mas ludzi.

Odnosząc się do pytania, jak mierzyć efektywność działalności obywatelskiej, należy stwierdzić, że najlepszym sposobem są badania jakościowe, określające wpływ danego instrumentu partycypacji społecznej na świadomość mieszkańców. W drugiej kolejności należy zobrazować go pod względem ilościowym. Wydaje się, że podstawowymi efektami podejmowania przez społeczeństwo aktywności obywatelskiej jest zmiana postaw społecznych, zwiększenie się sieci relacji między członkami wspólnoty, wytworzenie nowych więzi społecznych, zmiana zachowań wyborczych oraz zwiększenie zainteresowania sprawami publicznymi.

Podsumowując, warto rozważyć każdy z przedstawionych modeli budżetu partycypacyjnego jako instrumentów wpływających na rozwój społeczeństwa obywatelskiego na Ukrainie. Przede wszystkim 
Mateusz Radziszewski - Partycypacja budżetowa...

należy zastanowić się, które z rozwiązań z Porto Alegre i Łodzi jest w stanie przezwyciężyć kluczowe problemy i wypaczenia w wymiarze ukraińskiego społeczeństwa obywatelskiego.

W pierwszej kolejności kwestią negatywnie wpływającą na zaangażowanie obywatelskie na Ukrainie jest brak transparentności sfery organizacji pozarządowych. W tym przypadku model brazylijski sprawdza się doskonale, gdyż w ramach działania budżetu partycypacyjnego to nie poszczególne organizacje, lecz mieszkańcy miasta biorą udział w tworzeniu projektów. Nie można tego powiedzieć o modelu łódzkim, który wielokrotnie bywał zdominowany przez organizacje pozarządowe, odznaczające się większym kapitałem społecznym, będąc zdolne do mobilizacji i organizacji „swoich wyborców”, nie dając szans ludziom niezrzeszonym, chcącym zabrać głos i zmienić lokalną rzeczywistość.

Następnie rozważając wzmocnienie zaangażowania obywateli w sferze publicznej, można stwierdzić, że wykorzystanie nowych technologii oraz Internetu $w$ procesie tworzenia oraz przeprowadzania kolejnych edycji Budżetu obywatelskiego dla Łodzi stanowi atut tego modelu. Pozwala on na niemal nieograniczony dostępu obywateli do informacji publicznej, a tym samym podnoszenia ich świadomości o bieżącej polityce lokalnej.

Kolejną kwestią jest zbudowanie płaszczyzny zaufania między obywatelami, a władzami. W tym przypadku trudno ocenić, który z modeli byłby lepszym w wymiarze samorządu ukraińskiego. Należy stwierdzić, że są one równie dobre, umożliwiając na współpracę wszystkich podmiotów. Zaangażowanie dużych mas społecznych, tak jak w przypadku brazylijskim oraz podzielenie się odpowiedzialnością pomiędzy różne kolegia za stworzenie wspólnego programu rozwoju miasta, zdaje się w pewnym stopniu przeciwdziałać przypadkom klientelizmu oraz korupcji. Podobnie jest w przypadku łódzkiego budżetu partycypacyjnego, gdzie ostateczna decyzja zostaje podjęta przez mieszkańców miasta w tajnym głosowaniu, a organizatorzy przedsięwzięcia mają jedynie za zadanie zliczenie wyników poszczególnych projektów 
i podanie ich do informacji publicznej. Wydaje się, że oba rozwiązania są wobec siebie komplementarne i mogą zostać wykorzystane w perspektywie reform na Ukrainie.

Kolejną kwestią jest potrzeba wzmocnienia relacji między podmiotami społecznymi, a administracją publiczną. $\mathrm{W}$ tym przypadku budżet brazylijski prezentuje jak należy stworzyć doskonałą płaszczyznę do dialogu i współpracy przedstawicieli administracji publicznej, naukowców oraz mieszkańców miasta. W przypadku Łodzi, z racji dużej anonimowości podczas zgłaszania projektów oraz głosowania na nie, kontakt ten jest znacznie utrudniony.

W dalszej kolejności warto zastanowić się nam wzywaniem, jakim jest promocja dobrego rządzenia poprzez stworzenie odpowiednich ram prawnych dla efektywniejszego świadczenia usług publicznych. Tutaj również model brazylijski, jako otwarte forum debaty, mogłoby stać się pomocnym narzędziem nie tylko do projektowania proporcji do budżetu miasta, ale również jako płaszczyzna wypracowywania wspólnych rozwiązań prawnych. Zbudowane w ramach tego modelu więzi społecznych między mieszkańcami oraz nawiązanie dobrych relacji z administracją pozwoli wykorzystać ten instrument do wielu inicjatyw w zakresie samorządu lokalnego. To istotny wniosek, który powinien być obiektem dalszych badań politologicznych.

Ostatnią kwestią jest to, jak można umożliwić możliwie najszerszej reprezentacji społeczeństwa udział w procesie decyzyjny zarówno na szczeblu lokalnym jak i krajowym. W tym przypadku łódzki model budżetu partycypacyjnego wydaje się być odpowiedni, gdyż w łatwy sposób potrafi angażować dużą liczbę obywateli. Jest on jednak przeprowadzany niejako na zasadach referendum, zatem nie stanowi innowacji w zakresie partycypacji politycznej. Model brazylijski byłby tutaj bardziej innowacyjny. Jego zastosowanie pozwoliłoby na stworzenie wielkiej społecznej sieci, która stanowiłaby cały mechanizm podejmowania decyzji. Jednakże $\mathrm{w}$ wymiarze krajowym mógłby on być z powodu skali dysfunkcyjny, dlatego należy wskazać, że przedstawione modele partycypacji społecznej w pierwszej kolejności po- 
winny być wykorzystywane w wymiarze lokalnym. Na obecnym etapie badań brak dowodów mówiących o tym, że na wyższym poziomie administracji publicznej spełniają one swoje role w należyty sposób.

Obecnie w ukraińskich mediach i polityce toczy się debata nad wdrażaniem lokalnych społeczności w sprawy samorządów. Przedstawiane propozycje skupiają się na rozwoju konsultacji społecznych. Postulaty pojawiające się $\mathrm{w}$ dyskusji to poszerzanie dostępu do informacji oraz uprawnień obywateli do wygłaszania własnych opinii. $\mathrm{Z}$ pewnością $\mathrm{w}$ ramach tych prac pomocnym będzie wykorzystanie jednego z przedstawionych tu modeli partycypacji społecznej. Z przeprowadzonej analizy wynika, że to model brazylijski byłby tym, który w bardziej komplementarny sposób pozwoliłby Ukraińcom przezwyciężyć problemy i nadużycia jakie występują w przestrzeni ich społeczeństwa obywatelskiego. Przemawia za tym również historia obu tych krajów. Brazylia, podobnie jak i Ukraina, znajdując się przed wyzwaniem stworzenia nowego ładu wewnątrz kraju, zaraz po transformacji systemowej, musiała zmierzyć się z wieloma problemami w sferze społecznej, politycznej i gospodarczej. Nie było to jednak odstraszające dla nowych władz, a wręcz przeciwnie. Zmotywowało je to do rewolucyjnej zmian $w$ sferze relacji społecznych podnosząc znaczenie obywateli, niejako na nowo definiując ich podmiotowość. Dlatego też wydaje się, że rozwiązaniem jakie należy rekomendować jest wykorzystanie brazylijskich doświadczeń w zakresie rozwoju społeczeństwa obywatelskiego. Naturalnie decyzja pozostaje w gestii władz i społeczeństwa Ukraińskiego. Pozostaje tylko wyrazić nadzieję, że niniejszy artykuł stanie się dla wielu reformatorów oraz osób, którym bliska jest idea rozwoju społeczeństwa obywatelskiego, bez względu na kraj pochodzenia, drogowskazem pozwalającym podjąć dobre decyzje i zastosować takie instrumenty, które umożliwią jak największy rozwój społeczny rozmaitych zbiorowości. 


\section{Bibliografia:}

Allegretti G., Herzberg C., Participatory budgets in Europe. Between efficiency and growing local democracy, Amsterdam 2004.

Arystoteles, Polityka, Warszawa 2006.

Baiocchi G., Participation, activism, and politics: The Porto Alegre experiment and deliberative democratic theory, „Revised” 1999, Vol. 11.

Baur A., Szwajcarski fenomen, Warszawa 1993.

Chodubski A., Ukraina a procesy przemian europejskich. Przeszłość i teraźniejszość, „Eastern Review” 2014, T. 3.

Ciastocha M., Ukrainiec najbiedniejszy w Europie. Sprawdź, na co go stać, „Newsweek” 31.03.2015, http://swiat.newsweek.pl/ile-zarabiaja-ukraincy,artykuly,360185,1.html

Civil Society And The Crisis In Ukraine, OECD SEC.FR/125/15/ 4 March 2015, s. 4, http://www.osce.org/ukraine-smm/141046?download=true.

Czapiński J., Panek T., Diagnoza Społeczna 2015 - Warunki i jakość życia Polaków, Warszawa 2015, http://parlament2015.pkw.gov.pl/349_wyniki_sej m.

Dresen F., Media in Ukraine: A Domain of the State, the Oligarchs, or the Public?, https://www.wilsoncenter.org/publication/media-ukraine-domainthe-state-the-oligarchs-or-the-public\#sthash.REhdggxR.dpuf.

Ganuza E., Francés F., The deliberative turn in participation: the problem of inclusion and deliberative opportunities in participatory budgeting , „European Political Science Review" 2012, Vol. 4.

Ganuza E., Nez H., Morales E., The Struggle for a Voice: Tensions between Associations and Citizens in Participatory Budgeting, „International Journal of Urban and Regional Research" 2014, Vol. 38, No. 6.

Gianpaolo B., Militants and Citizens. The Politics of Participatory Democracy in Porto Alegre, Stanford 2005.

Giroux H. A., Bhattacharya D., Anti-politics and the scourge of authoritarianism, „Social Identities” 2016.

Górski R., Bez państwa, Wyd. Korporacja Ha!art, Warszawa 2007.

Kacewicz M., Nowa wojna oligarchów na Ukrainie, „Newsweek” 2015, http://swiat.newsweek.pl/oligarchowie-rzadza-ukraina,artykuly,35978 9,1.html.

Kębłowski W., Budżet partycypacyjny, krótka instrukcja obsługi, Warszawa 2013. 
Mateusz Radziszewski - Partycypacja budżetowa...

Kille L. W., Citizen participation in municipal budgeting: Origins, practices, impact, „Journalist's Resources” 2013.

Klamut R., Aktywność obywatelska jako rodzaj aktywności społecznej - perspektywa psychologiczna, „Studia Socjologiczne” 2013, nr 1 (208).

Konsevych O., Wyjechać aby przeżyć. Emigracja $w$ krajach Partnerstwa Wschodniego, http://www.eastbook.eu/blog/2013/08/19/wyjechac-aby -przezyc-emigracja-w-krajach-partnerstwa-wschodniego.

Kraszewski D., Mojkowski K., Budżet obywatelski w Polsce, Warszawa 2014.

Krauski M., Społeczeństwo obywatelskie na Ukrainie, http://www.forum-ekonomiczne.pl/article/spoleczenstwo-obywatelskie-na-ukrainie/\#.VqTDbf nhCHs.

Ludność - dane o Łodzi 2014, http://lodz.stat.gov.pl/dane-o-wojewodztwie/ stolica-wojewodztwa-1323/ ludnosc-dane-o-lodzi-2014.

Marquetti A., Schonerwald da Silva C. E., Participatory Economic Democracy in Action: Participatory Budgeting in Porto Alegre. 1989-2004, Salt Lake City 2009.

Opinia Europejskiego Komitetu Ekonomiczno-Społecznego w sprawie sytuacji ukraińskiego społeczeństwa obywatelskiego w kontekście europejskich aspiracji Ukrainy, REX/403 Bruksela, 16 października 2014, http://eurlex.europa.eu/legal-content/PL/TXT/?uri=CELEX\%3A52014IE3088, 25.01.2016.

Prykowski Ł., Głos łodzian się liczy - czyli doświadczenia z budżetem obywatelskim $w$ radach osiedli, Łódź 2012.

Putnam R., Demokracja $w$ działaniu. Tradycje obywatelskie we współczesnych Włoszech, Warszawa 1993.

Putnam R., Samotna gra w kręgle, upadek I odrodzenie wspólnot lokalnych w Stanach Zjednoczonych, Warszawa 2008.

Raport socjologów na temat jakości życia mieszkańców Łodzi, http://nauka wpolsce.pap.pl/aktualnosci/news,392990,raport-socjologow-na-temat-ja kosci-zycia-mieszkancow-lodzi.html.

Sánchez S., Aragonès E., A Model of Participatory Democracy: Understanding the Case of Porto Alegre, Edinburgh 2004.

Santos B. de S., Participatory budgeting in Porto Alegre: Toward a redistributive democracy, „Politics \& Society” 1998, Vol. 26, No. 4.

Serzysko E. (red.), Standardy procesów budżetu partycypacyjnego w Polsce, Warszawa 2014. 
Sintomer Y., Herzberg C., Allegretti G., Röcke A., Learning from the South: Participatory Budgeting Worldwide - an Invitation to Global Cooperation, Bonn 2010.

Sintomer Y., Herzberg C., Röcke, A., Démocratie participative et modernisation des services publiques: des affinités électives? Les budgets particiatifs en Europe, Paris 2007.

Souza C., Participatory budgeting in Brazilian cities: limits and possibilities in building democratic institutions, „Environment \& Urbanization” 2001, Vol.13, s. 161, http://www.ucl.ac.uk/dpu-projects/drivers_urb_change/ urb_governance/pdf_part_budg/IIED_Souza_Budgeting_Brazil.pdf.

Trykozko R., Ekspertyza prawna dotyczaca możliwości wprowadzania budżetu obywatelskiego w miastach, Warszawa 2013. 